\title{
Entrepreneur Business Development in Sindh: The Case of Jacobabad District
}

\author{
Dr. Nadeem Bhatti \\ Head of Faculty, North American College \\ 730-Yonge Street, Suite No. 207, Toronto, Ontario, M4Y 2B7, Canada \\ Faiz.M.Shaikh \\ Department of Agri. Economics, SZABAC-Dokri-Larkana, Sindh-Pakistan \\ E-mail:faizsaikh@hotmail.com \\ Amir Hussain Shar \\ Department of Commerce, Shah Abdul Latif University, Khairpur \\ M.Saleem Rahpoto \\ Department of Economics, Shah Abdul Latif University, Khairpur \\ Muhammad Shahzad Iqbal \\ Department of Business Administration, University Of Faisalabad, Faisalabad
}

\begin{abstract}
The research analyzes the impact of SMEs business opportunities for entrepreneurs in Jacobabad District, The strategic development option for local economic development, especially in the rural areas of Sindh. Data were collected from 300 respondents by using simple random technique. A structural questionnaire was designed to get the reliable results. This strategy being also known as homegrown development refers to a process of supporting and encouraging people to become entrepreneurs in order to enhance the economic prosperity of a community, first, creating the environment being favorable for creativity and innovativeness; second, encouraging entrepreneurship as an eligible career option through entrepreneurial education, facilitation and recognition, and third, developing institutional support system to entrepreneurs. The main aim of this paper is to discuss the economic strength of small and medium-sized enterprises (SMEs) in the economic development of Jacobabad District, and to explore the perception of the Jacobabad entrepreneurs about the role of institutions in entrepreneurship development. The analysis indicates the SMEs have had a weak economic power. Small and medium-sized enterprises, although numerically overwhelming, employ approximately half of the total employed in the City, operate continuously with financial losses, and are oriented mostly to doing business locally. According to the perception of Jacobabad entrepreneurs, the biggest business challenges are caused by problems connected to entrepreneurial environment conditions, i.e. institutional infrastructural conditions, and the least to inappropriate profiles and inefficiency of local work force. Drown from these findings, lessons considering the process of entrepreneurship development in Jacobabad District is discussed as well. It was revealed that government should provide facilities to the entrepreneurs, credit and market facilities. It was further revealed that Rural people are facing lot challenges specially their women who are engaged in Small and Medium enterprises business. Rural women is more innovative once they are engaged in SMEs business, these illiterate women have more innovative designing of various suits, local handicraft, and other SMEs businesses
\end{abstract}

Keywords: Entrepreneurship, Development, Jacobabad, Sindh

\section{Introduction}

The first part of current research paper highlights the various aspects of SMEs in terms of Entrepreneur development and their impact on the Growth of SME business and their contribution to Pakistan economy by suing various data indicators. Finally, conclusions and suggestions about the SMEs business growth and possible solution on export oriented products which can be marketed in Globalize world of business. Economic development refers to a qualitative process that describes changes in the overall economy aiming to enhance the economic well-being of a community regardless of its size. In economic literature, economic development is frequently described as being a three-legged stool where each leg represents one economic development strategy. The first leg usually refers to business attraction; the second one to business retention and the third one to entrepreneurship development. However, because this analogy assumes the existence of equality and separation among economic development strategies, more useful analogy is that of a pyramid as Dabson (2005) pointed out 


\section{Definition of SMEs in Pakistan}

The Pakistan SMEs are engaging in wide rage of business activities in agriculture, mining fishing industry /manufacturing, construction retail and whole sales and services in rural urban and estate setting by servicing local and international. They are active in most of the industry sub sectors such as agricultural inputs/outputs business in rural areas to food and beverages business in city up to more advanced light engineering sectors such as computer, chemical machinery. Apparel and person show or are run by few family individuals, usually relatives, friends or business partners who take most of the decisions. Usually no distinction between private and business assets and subjective and personal factors play a large role in decision making. The personal stakes of Pakistan SMEs have in their business are much higher than those of corporate executives in their companies. This enhances the attendant and commits entrepreneurs even more strongly to the success of their enterprises. Most Pakistani SMEs in informal sector are reposting very low productivity and income therefore owners and worker are working poor high income and decent life for workers and owners this wide variation of diversity turnover/revenue, sophistication, innovation, productivity and growth orientation due to this complexity it is very hard to defines SMEs overtime in Pakistan and currently nationally acceptable single definition is not available. There are very many definitions available based on assets, employees skills capital turnover/revenue in local and exports markets, sophistication, and innovation productivity and growth orientation. But most of these definitions are made according to organizational needs and purpose of interests about SMEs. Financial institution public sector authority non-government organizing (NGOs) Trade and industry chambers international organizations researchers SMEs such as criteria selection Most of these organization used various terms for SMEs such as Small and Medium Scale Industries (SMEs) Micro Enterprises (Mes), Rural Enterprises (Res), Small and Medium Scale Activities (SMAs), Cottage and Small Scale Industry (CSSI), Informal Sector Activities (ISAs), Micro and Small Scale Activities (MSSA) etc, Generally, enterprise is defined as any business activity or entity engaged in industry agri-business and /or services whether singles proprietorship, partnership or corporate venture. This enterprise definition is universally accepted around the World .The following table shows most popular definitions of SMEs available in Pakistan.

\section{The Role of SMEs in Economic Development of Jacobabad}

The term small and medium-sized enterprises (SMEs) refers to the business based on legal and physical persons (companies, craftsmen and others) who, independently and permanently, pursue the allowed activities to gain profit, i.e. the income on the market. SMEs actors can be categorized into micro, small and medium-sized enterprises. Micro enterprises have less than 10 employees per year, small enterprises have less than 50 employees per year, and medium-sized enterprises have less than 250 employees per year. A precise definition of micro, small and medium-sized enterprises is provided by the Small and Medium Business Development Authority (SAMEDA-2009). A brief analysis of SMEs and their contribution to the development of Jacobabad District that follows in the continuation of this paper is based on survey-2009-10 on active enterprises. In the size-class structure of the Jacobabad enterprises, small enterprises are dominating (see table 1). Their share has been stabilized at the level of approximately $95 \%$. The share of large enterprises accounts approximately $2 \%$. The rest of $100 \%$ belongs to medium-sized enterprises.

Work done by McMillan and Woodruff (2002) pointed out to their role that they have in transformation of the economy from the centrally planned to market economy. However, some of scholars raised doubt about their role in assisting growth and promoting innovation since SMEs, as they said, are more engaged in their survival on a day-to-day basis (Grey, 1998). The European Union (EU) has the same size-class structure of enterprises. 99\% of total enterprises in the EU are small enterprises ( $0-49$ employees), less than $1 \%$ is medium-sized (50-249) and only $0.2 \%$ is large enterprises $(250+)$.

\section{Data Collection Methodology}

Data were collected from 300 SMEs entrepreneurs by using simple random technique a structural questionnaire was design as an instrument tool for measuring the SMEs performance in Jacobabad. Data were analysis by using E-Views 6 statistical software.

The share of long-term asset and long-term financial asset of small and medium-sized enterprises in the total asset of Jacobabad entrepreneurs accounted $24.38 \%$ and $23.11 \%$ respectively in 2004 . Such shares of assets indicate that economic power is still concentrated in large enterprises. Financial power of enterprises by size-class is shown in table 3. Only large enterprises operated financially efficient.

Poor Financial Results of SMEs are connected with their Poor Export Aggressiveness 
In this research, entrepreneurs are more willing to emphasis the issues of macroeconomic characters and to express dissatisfaction with the general national framework conditions. However, entrepreneurs should not forget that they are the key of productiveness, competitiveness and export expansion as well as of better business results. Only with on-going investments in knowledge and skills of their employees, innovativeness of the whole business operations and products, new value added creation in all phases of business processes, and with meeting the excellence in them, it is possible to make products that are market demanded on the global market, and that are competitive regarding their quality and price.

\section{Towards Entrepreneurial Management of the Jacobabad}

Entrepreneurship development is a process of supporting and encouraging people to become entrepreneurs whereby entrepreneurship policy and programs aimed to create a favorable and supportive entrepreneurial environment within creativity, diversity, tolerance and on-going innovativeness will be encouraged; promote an entrepreneurship as an eligible career option and in general to develop entrepreneurial culture; develop an efficient and effective institutional support system to entrepreneurs. An important step in entrepreneurial management represents understanding the issues with which entrepreneurs have been facing. It can guide the local entrepreneurship policy and programs. Enhancing the quality of entrepreneurial environment is especially important task; the more favorable and supportive the entrepreneurial environment is the more number of entrepreneurs will base their growth and development on export strategy.

\section{Perception of entrepreneurial environment quality in the Jacobabad District}

The term "entrepreneurial environment" refers to a mix of factors that influence the development of entrepreneurship. According to GEM, entrepreneurial environment or entrepreneurial framework conditions are described by contextual factors such as: financial support, government policies and programs, education and training, R\&D transfer commercial and legal infrastructure, internal market openness and competitiveness, access to physical infrastructure as well as cultural and social norms. These conditions are also evaluated for Croatia and their quality is compared to other GEM countries. According to Croatian experts that were interviewed in the frame of GEM research and whose opinions were served as a basis for evaluation, entrepreneurial framework conditions have been mostly unfavorable; however, in 2005 and 2006 compared with previous years, improvement in quality of the conditions are noticed (see Singer at al., 2006; 2007). Slightly more than 50\% of respondents assessed that the entrepreneurial framework conditions in the Jacobabad District are bad or very bad, while only $19 \%$ that they are good or very good. The most important challenges in their operation are the challenges associated to institutional infrastructure of entrepreneurial environment (figure 1), and the least ones to inadequate profile of labor force. Baumol (1990) pointed out the importance of institution in creation of so called "rules of game" and in fostering the entrepreneurial activity in a country. Sautet (2005) emphasized that institutions are vital to the expansion of entrepreneurial activity, which is at the heart of the process of development and economic growth. According to Sautet, quality of institutions is the main determinant of productive entrepreneurship. Dallago (1997) tested the importance of institutions in a transitional setting and he concluded that social institutions have more important role in economic performance and economic growth through allocation of entrepreneurs on productive and unproductive, than the entrepreneur supply alone has. Many scholars who explored the role of institutions in entrepreneurship indicated its importance as well (e.g. Hart, 2003; Dallago; 2005; Aidis and Estrin, 2005). Thus, it is important to evaluate the efficiency and effectiveness of institutions and their contribution to the entrepreneurship development and economic growth.

\section{Conclusion}

This research explores the performance of SMEs business in Jacobabad District. Rural people are facing lot challenges specially their women who are engaged in Small and Medium enterprises business. Rural women is more innovative once they are engaged in SMEs business, these illiterate women have more innovative designing of various suits, local handicraft, and other SMEs businesses. Rural people are facing with poor economic situations at the beginning of $21^{\text {st }}$ century. It was also observed that most of the women have been killed in Karo Kari and those feudal lords are saying honour killing. In these situation rural women is still self dependent and feeding their whole family. Thus, the economic gap between these cities and Jacobabad has becoming increasingly larger. Formulation and implementation of entrepreneurship development strategy can contribute to community's faster and more qualitative development. Since entrepreneurship development strategy is directed to a process of supporting and encouraging people to become entrepreneurs in order to enhance the economic prosperity of a community, it is suitable for development of rural or depressed areas as it is the region Slavonia and Baranja. The entrepreneurship development depends on the quality of entrepreneurial framework conditions, including in which extent the environment and entrepreneurial climate support creativity, diversity, tolerance and continuous 
innovativeness, in which extent 'can-do' mentality has been developed (in a sense are people willing to accept risk, what they think about business failures), and how efficient and effective is the institutional support. The brief analysis conducted in this paper indicates that the SMEs have had a weak economic power. Even tough they are numerically overwhelming; they employ approximately half of the total employed in the City, operate continuously with financial losses, and are oriented mostly to doing business locally. According to the perception of Jacobabad entrepreneurs, the biggest business challenges are caused by problems connected to entrepreneurial framework conditions, i.e. institutional infrastructural conditions, and the least to inappropriate profiles and inefficiency of local labor force. Drown from these findings; we can conclude that entrepreneurial management system of the Jacobabad District should be redefined and that the synergic effects failed.

\section{References}

Acs, Z. (2007). Entrepreneurship, Economic Growth and Public Policy, Small Business Economics, Vol. 28, 2.

Aidis, R. (2003). Entrepreneurship and Economic Transition, Tinbergen Institute, Discussion paper, TI2003-015/2, 1-29.

Aidis, R., Estrin, S. (2005). Weak Institutions, Weak Ties and Low Levels of Productive Entrepreneurship in Russia: An Exploration, draft, December.

Audretsch, D. B., Thurik, R.A. (2000). Capitalism and Democracy in the $21^{\text {st }}$ Century: From the Man-aged to the Entrepreneurial Economy, Journal of Evolutionary Economics, 10.

Audretsch, D.B., Keilbach, M.C., Lehman, E.E. (2006). Entrepreneurship and Economic Growth, Oxford University Press, USA.

Baumol, W.J. (1990). Entrepreneurship: Productive, Unproductive and Destructive, Journal of Political Economy, 98, 5(1).

Borozan, Dj. (2006). Drustveno-ekonomska dimenzija razvoja Grada Jacobabad a, in: Strategy of the Jacobabad District, Singer, S. (ed.), draft version.

Carree, M., Thurik, R. (2005). Understanding the Role of Entrepreneurship for Economic Growth, Max Planck Institute of Economics, Discussion Papers on Entrepreneurship, Growth and Public Policy, no. 2005-10.

Dabson, B. (2005). Regional Competitiveness, Innovation and Entrepreneurship, Economic Development and the University of Missouri-Columbia, Framing the Debate, Working Paper no. 1.

Dallago, B. (1997). The Economic System, Transition and Opportunities for Entrepreneurship, Ch. 7, in Entrepreneurship and SMEs in Transition Economies, The Visegrad, Conference, Paris: OECD.

Dallago, B. (2005). Institutions and Entrepreneurship: A Comparative Evaluation of South-Eastern Europe, Working Paper no. 1.

Grey, C. (1998). Enterprise and Culture, London, Routledge.

Hart, D.M. (ed.). (2003). Emergence of Entrepreneurship Policy, Governance, Start-Ups, and Growth in the US Knowledge Economy, Harvard University, Massachusetts.

McMillan, J. \& Woodruff, C. (2002). The Central Role of Entrepreneurs in Transition Economies, Journal of Economic Perspectives, 16, 3, Summer.

NCE - National Commission on Entrepreneurship: Rebuilding Urban Neighborhoods: Entrepreneurship \& Community Development, $\quad$ February 2002 http://www.zeromillion.com/entrepreneurship/ncoe/community-development.html (accessed June 21, 2007)

Sautet, F. (2005). The Role of Institutions in Entrepreneurship: Implications for Development Policy, Mercatus Center, George Mason University, February.

Singer, S., Sarlija, N., Pfeifer, S., Borozan, Dj., Oberman Peterka, S. (2006). Sto cini Hrvatsku poduzetnickom zemljom?, Rezultati GEM 2002-2005 za Hrvatsku, CEPOR, Zagreb.

Singer, S.; Sarlija, N., Pfeifer, S., Borozan, Dj., Oberman Peterka, S. (2007). Sto cini Hrvatsku poduzetnickom zemljom? Rezultati GEM 2006 za Hrvatsku, CEPOR, Zagreb.

Singer, S. (2006). Od industrijskog do inteligentnog grada, in: Strategy of the Jacobabad District, draft version, Singer, S. (ed.).

Sober, R.S. (2006). Testing Baumol: Institutional Quality and the Productivity of Entrepreneurship, Dept. of Economics, West Wirginia University, Working Paper no. 06-06. 
Snijders, J., van der Horst, R. (2002). SMEs in Focus: Main Results From the 2002 Observatory of European SMEs, Observatory of European SMEs, Office for Official Publications of the European Communities, Luxembourg.

Small Business Development Promotion Act, Official Gazette, 29/2002.

Wennekers, S.\& Thurik, R. (1999). Linking Entrepreneurship and Economic Growth, Small Business Economics, 13,1 .

Table 1. The size-class Structure of Jacobabad Enterprises

\begin{tabular}{|l|l|l|l|l|l|l|l|}
\hline & \multicolumn{2}{|l|}{ Number of enterprises } & \multicolumn{3}{l|}{ Share portion in \% Economic } \\
\hline & Small & Medium-sized & Large & Total & Small & Medium-sized & Large \\
\hline 2002. & 600 & 60 & 33 & 693 & 45 & 10 & 5 \\
\hline 2003. & 711 & 61 & 36 & 808 & 47 & 11 & 4 \\
\hline 2004. & 714 & 64 & 37 & 815 & 50 & 09 & 5 \\
\hline 2005 & 800 & 70 & 40 & 910 & 52 & 09 & 4 \\
\hline 2006 & 813 & 72 & 42 & 927 & 51 & 08 & 5 \\
\hline 2007 & 1100 & 78 & 42 & 1220 & 52 & 09 & 6 \\
\hline 2008 & 1200 & 81 & 45 & 1326 & 53 & 10 & 5 \\
\hline 2009 & 1260 & 89 & 48 & 1397 & 54 & 09 & 4 \\
\hline
\end{tabular}

Source: Survey 2009-10

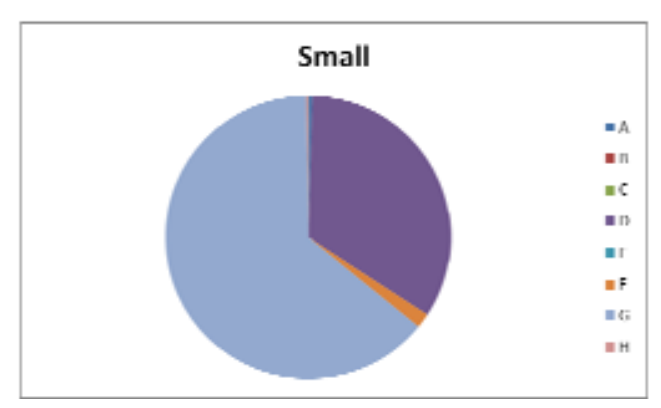

Table 2. Number of Employees (Situation at the end of period)

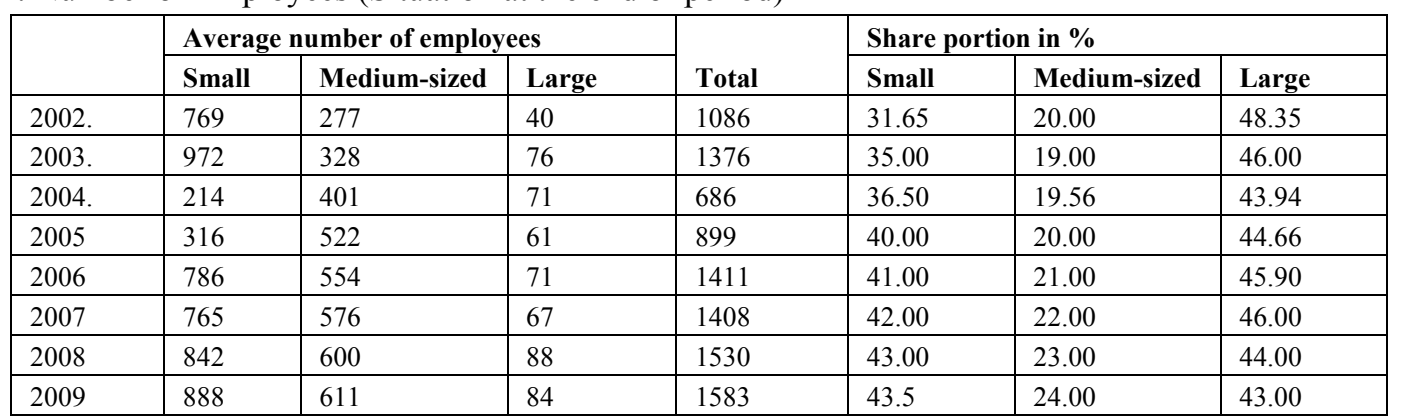

Source: Survey-2009

Average number of employees Small

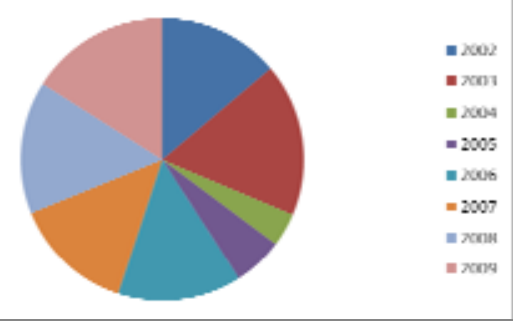


Table 3.The basic financial indices of Jacobabad District entrepreneurs by size-class

\begin{tabular}{|c|c|c|c|c|c|c|c|c|c|}
\hline & \multicolumn{3}{|l|}{ Small } & \multicolumn{3}{|c|}{ Medium-sized } & \multicolumn{3}{|l|}{ Large } \\
\hline & Earning & Loss & $\begin{array}{l}\text { Financial } \\
\text { Result }\end{array}$ & Earning & Loss & $\begin{array}{l}\text { Financial } \\
\text { Result }\end{array}$ & Earning & Loss & $\begin{array}{l}\text { Financial } \\
\text { Result }\end{array}$ \\
\hline A & 632.38 & 779.28 & -146.90 & 758.06 & 623.75 & 134.30 & & & \\
\hline $\mathrm{B}$ & 0.66 & & & & & & & & \\
\hline $\mathrm{C}$ & 61.68 & 313.04 & -251.36 & & & & & & \\
\hline $\mathrm{D}$ & 3719.48 & 4117.58 & -398.10 & 614.47 & 2580.74 & -1966.27 & 30031.09 & 11181.33 & 18849.76 \\
\hline $\mathrm{E}$ & & & & & & & 330.78 & & 330.78 \\
\hline $\mathrm{F}$ & 1178.54 & 1074.41 & 104.12 & 620.27 & 0.00 & 620.27 & 3072.18 & & 3072.18 \\
\hline $\mathrm{G}$ & 7247.29 & 19294.78 & -12047.49 & 2174.52 & 295.63 & 1878.89 & 10592.39 & 591.59 & 10000.80 \\
\hline $\mathrm{H}$ & 124.35 & 675.98 & -551.63 & & 1531.20 & -1531.20 & 0.00 & & \\
\hline I & 582.80 & 327.79 & 255.01 & 69.31 & 564.07 & -494.76 & 248.54 & & 248.54 \\
\hline $\mathrm{J}$ & 437.56 & 8440.42 & -8002.86 & & & & & & \\
\hline $\mathrm{K}$ & 3955.92 & 1636.82 & 2319.10 & 688.58 & 20765.30 & -20076.71 & & & \\
\hline $\mathrm{M}$ & 75.61 & 4.81 & 70.80 & & & & & & \\
\hline $\mathrm{N}$ & 14.26 & 0.17 & 14.09 & & & & & & \\
\hline $\mathrm{O}$ & 687.59 & 262.47 & 425.12 & 7.63 & & 7.63 & 125.68 & & 125.68 \\
\hline Total & 18718.12 & 36927.54 & -18210.09 & 4932.84 & 26360.69 & -21435.48 & 44400.66 & 11772.92 & \\
\hline
\end{tabular}

1. Source: Survey-2009

2. Code: A - agriculture, hunting and forestry; B - fishing; $\mathrm{C}$ - mining and quarrying; D - manufacturing; $\mathrm{E}$ - Electricity, gas and water supply; F - construction; $\mathrm{G}$ - wholesale and retail trade, repair of motor vehicles, motorcycles and personal and household goods; $\mathrm{H}$ - hotels and restaurants; I - transport, storage and communication; J - financial intermediation; $\mathrm{K}$ - real estate, renting and business activities; $\mathrm{L}$ public administration and defense, compulsory social security; $\mathrm{M}$ - education; $\mathrm{N}$ - health and social work; $\mathrm{O}$ - other community, social and personal service activities

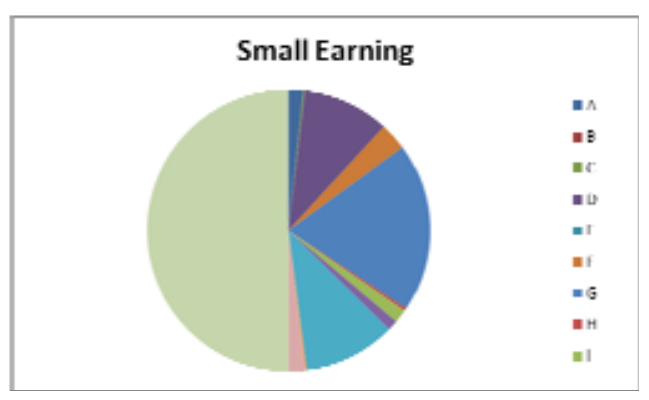

Table 5. Income generated abroad by size-class of Enterprises in 2009

\begin{tabular}{|l|l|l|l|l|l|l|}
\hline & & & & & \multicolumn{2}{l}{ Share portion in \% } \\
\cline { 5 - 7 } & Small & Medium-sized & Large & Large & Medium-sized & Small \\
\hline A & 108.93 & & & 0.04 & & \\
\hline B & & & & & & \\
\hline C & & & & & & \\
\hline D & 8123.73 & 3426.51 & 228561.87 & 2.90 & 1.22 & \\
\hline E & & & & & & 81.68 \\
\hline F & 405.89 & 462.26 & 877.77 & 0.15 & 0.17 & 0.31 \\
\hline G & 15378.33 & 2891.13 & 9806.15 & 5.50 & 1.03 & 3.50 \\
\hline H & 62.67 & 6.96 & & 0.02 & & \\
\hline I & 2887.31 & 2985.97 & 1559.06 & 1.03 & 1.07 & 0.56 \\
\hline J & & & & & & \\
\hline K & 1426.41 & 519.96 & & 0.51 & 0.19 & \\
\hline M & & & & & & \\
\hline N & & & & & & \\
\hline O & 210.74 & 112.75 & & & & \\
\hline Total & 28604.02 & 10405.53 & & & & \\
\hline
\end{tabular}

Source: Survey-2009 
Code: A - agriculture, hunting and forestry; B - fishing; $\mathrm{C}$ - mining and quarrying; D - manufacturing; E - Electricity, gas and water supply; F - construction; $\mathrm{G}$ - wholesale and retail trade, repair of motor vehicles, motorcycles and personal and household goods; $\mathrm{H}-$ hotels and restaurants; I - transport, storage and communication; J - financial intermediation; $\mathrm{K}$ - real estate, renting and business activates; $\mathrm{L}$ - public administration and defense, compulsory social security; $\mathrm{M}$ - education; $\mathrm{N}$ - health and social work; $\mathrm{O}$ - other community, social and personal service activities

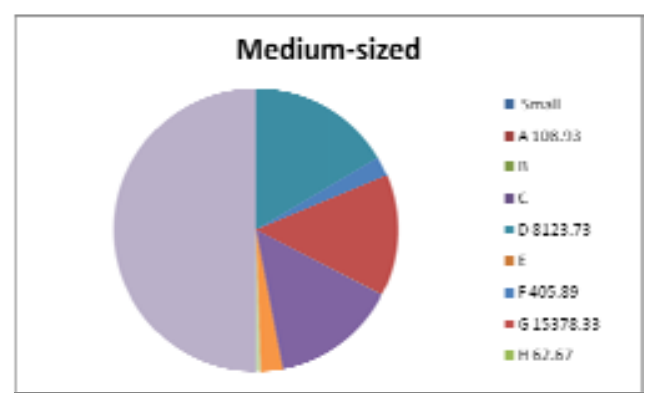

Table 6. Prerequisites of SMEs development in Jacobabad (entrepreneur perspective)

\begin{tabular}{|l|l|}
\hline Prerequisite & Mean \\
\hline Corruption elimination & 4.68 \\
\hline Reduction of informal economy & 4.67 \\
\hline Different and numerous financial sources & 4.35 \\
\hline Easier loan procedures & 4.27 \\
\hline Local government concern & 4.24 \\
\hline Cooperation among entrepreneurs & 4.13 \\
\hline State government concern & 4.13 \\
\hline Protection from foreign competition & 3.75 \\
\hline
\end{tabular}

Source: Survey-2009 